\title{
Value Chain Analysis of Backyard Poultry in Betanati Block, Mayurbhanj District, Odisha, India
}

\author{
Saswatik Tripathy ${ }^{1}$ and Punit Kumar Agarwal ${ }^{2 *}$
}

${ }^{1}$ Department Development Management. The DHAN Academy, Madurai, India

${ }^{2}$ Department of Agricultural Economics and Statistics, Kulbhaskar Ashram PG College, Prayagraj, Uttar Pradesh, India

*Corresponding author: punitagriculture@gmail.com (ORCID ID: 0000-0001-7208-5507)

Received: $15-04-2020$

Revised: $18-07-2020$

Accepted: 28-08-2020

\begin{abstract}
Backyard poultry is a low input or no input bird rearing practice and is characterized by indigenous night shelter system, scavenging system, with little supplementary feeding, natural hatching of chicks, poor productivity of birds local marketing and no health care practice which is usually takes place in back yard of rural household. This study has been done to understand the value chain of the back yard poultry in a depth manner in different stages. For the study the state, district and block has been selected purposively as this place was well known for the backyard poultry culture. The study is totally done by the help of sampling survey, FGD and some PRA tools. 60 samples of farmers 10 samples of middle man and 10 samples of consumers are taken to do the study. Sample of the farmers and consumers are selected by simple random sampling and the middle men are selected by the snowball sampling. Odisha is among one of the most vulnerable sufferer of the eastern coast cyclones, as the result of this the agriculture and the livestock which is the backbone of rural economy is badly affected. So the community focuses on the short term and low cost livestock backyard poultry to avoid a huge loss. In this study the system of back yard poultry has been studied clearly in all the stages, and sixteen different value chains are found. The detailed results and discussions are clearly elaborated.
\end{abstract}

\section{Highlights}

( In this study the value chain of backyard poultry is highlighted in a detailed manner.

Keywords: Backyard poultry, Value chain, B:C ratio, Odisha, India

Backyard poultry is a low input or no input bird rearing practice and is characterized by indigenous night shelter system, scavenging system, with little supplementary feeding, natural hatching of chicks, poor productivity of birds local marketing and no health care practice which is usually takes place in back yard of rural household. The history of backyard poultry is as ancient as the civilization. According to the article of Randhaea (1946) the Terracotta arts which are found in the MohenjoDaro and Harappa describing clearly that people domesticated the birds and domestic fowls called Gallus gallus domesticus and its ancestors red jangle fowls called Gallus gallus. This birds are originated from the North India and still rear in the northern part of India viz. from Kashmir to Assam and in Madhya Pradesh, Odisha, West Bengal and Godavari district of Andhra Pradesh. He also mentioned that Indus valley people kept them only for sports, and its breeding for the flesh was started very later. According to the National commission of agriculture 1976 cultivation of the poultry bird

How to cite this article: Tripathy, S. and Agarwal, P.K. (2020). Value Chain Analysis of Backyard Poultry in Betanati Block, Mayurbhanj District, Odisha, India. Economic Affairs, 65(3): 465-472.

Source of Support: None; Conflict of Interest: None
(क) 
can be done in the different agro climatic zones as the fowls have a good physical adaptability. Requirement of small space, low investment, quick return and well distributed return throughout the year make it more popular in the rural areas.

Raising of local poultry breeds in backyard is an important source of livelihood for the rural people of Orissa. $63 \%$ of the owners of the backyard poultry are Scheduled Tribes, 17\% Scheduled Castes and rest $20 \%$ owned by OBCs and other communities. Small holdings containing 1-3 hens per unit were found to be more efficient producer of eggs compared to those with 4 or more hens per unit. The major problem of the backyard poultry sector is high mortality. Average annual income from backyard poultry is ₹ 2200 per household although the variation across households is very large. When mortality is reduced, income per household increases by 18.1 per cent (Sethi, 2007).

Value chain is the process or activities by which a company adds value to an article, including production, marketing, and the provision of aftersales service. In the case of backyard poultry from the hatching of egg to the table it has a long journey.

\section{MATERIALS AND METHODS}

Betanati block, Mayurbhanj District of Odisha was selected as the study location purposively. Two Panchayats and one village from each block was randomly selected. A sample size of 60 was selected by simple random sampling in two different villages. 10 middleman of each level was selected from different market by simple random sampling. Markets for the study selected purposively which was coined by the community during the time of focused group discussion. 10 Consumers was selected from different market by simple random Sampling. Data was collected through participatory tool (Linkage diagram) and structured questionnaire. The schedule was made on the basis of research need and information of baseline study. A pre-testing of the draft structured questionnaire was done by interviewing of five sample respondents, later the structured questionnaire was modified based on the responses of sample respondents in the field. This data was collected during the time May-June of 2019. For the analysis and representation of data various mathematical and statistical tools was used.

\section{RESULTS AND DISCUSSION}

Odisha is the state where maximum its population stayed in the beautiful villages of the state. From the collected data during the study it was found that the average income of the area is nearly ₹ 25000 (24558) per family per year. Around 68 per cent of the population is farmers and others are landless and unskilled. In this situation one monsoon failure or a cyclone easily can break the resilience of the whole community. According to past experience and information this state is among one of the most vulnerable sufferer of the eastern coast cyclones, as the result of this the agriculture and the livestock which is the backbone of rural economy is badly affected. The animals like cow and goat which have a longer life cycle cannot survive in the cyclones and the population faces a huge loss. So, the community focuses on the short term and low cost livestock backyard poultry to avoid a huge loss.

\section{Source and breeds of the chicks}

To start a backyard poultry every person need to start with the chicks. But chicks cannot be artificially created at home they need to be purchased from neighbor, or take it in share (Vagavai), they can buy it from the market, or can get from $\mathrm{KVK}$, middleman or directly domesticate in the home from forest.

From the table 1, it is clear that no one purchess the chicks from anywhere. Either they take it in share from other otherwise they domesticate it from the forest. During the FGD and in the discussion at Mayurbhanj
Box 1: Sharing (Vagavagi) Method Vagavagi (Share) is a day old traditional method. In this method one poor family take a pair of chicks from a person who have more. Then he will rare and make them adult. As becoming adult the birds will lay eggs and hatch it. After hatching the chicks will be equally divided among the borrower and the giver. district KVK it was found that the KVK also provide chicks to the tribal villages as part of the tribal sub plan. KVK is not promoting any local breed of chicks they usually promote the Banaraja and Rainbow roster breed to the tribal areas. But tribal people like the indiginous breed more as a result they do not take the chicks seriously. From the data of interview schedules collected through sampling 100 per cent farmers like the indigenous breed for the cultivation. 
Table 1: Source of chicks

\begin{tabular}{ll}
\hline Source & Percentage \\
\hline Vagavai (Sharing) & 45 \\
Home Domestication & 55 \\
\hline
\end{tabular}

\section{Unit Ration of the Female and Male birds for cultivation}

The ratio of the female and male bird is a very essential factor to be considered. The ratio of the birds maintain the marginal productivity and the profitability of a flock. In the case of adult birds the males will not reproduce but they will help in the fertilization of the female. According to KVK professionals and District veterinary officer one male bird is enough to fertilize eight female birds, so the ideal ration (female/male) of the birds is 8 . Less than that will be a state of loss because the male bird need feed to survive.

From the Chart 1, we can say that the $57 \%$ household of the research area have a ratio of zero to two, $25 \%$ families have a ratio of 2.1-4, $12 \%$ families have a ratio of 4.1-6 in the folk, $3 \%$ household is having the ratio of $6.1-8$ and $3 \%$ household is having a ration of more than 8 . It shows that no one maintain the ratio of the birds in the flock.

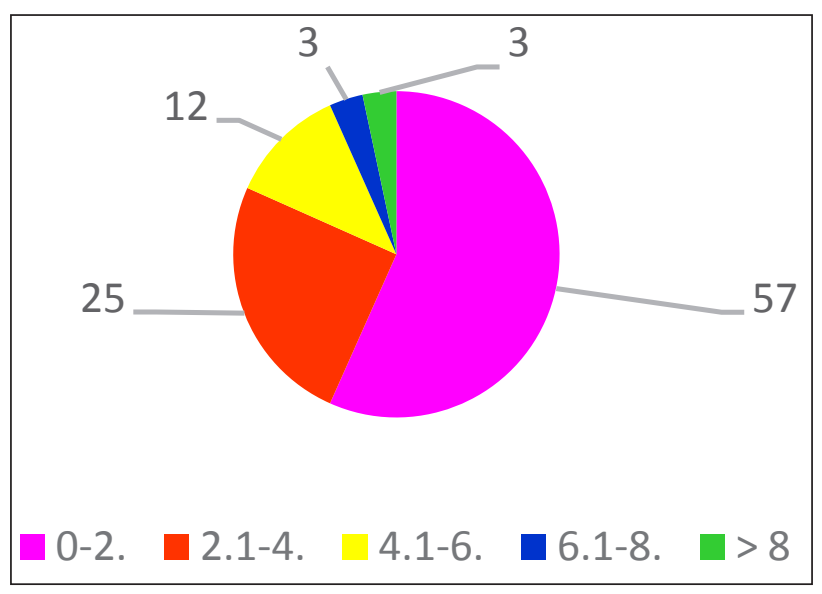

Chart 1: Ratio of the female and the male birds (Female/ Male)

\section{Method of production}

The production method which is followed by people all over the world are mainly three types open, cage or night shelter system.

Open method of production - In this case the birds are released for the scavenging and not given any shelter to stay, in case of rain they take shelter under any tree or under any shed outside available.
Cage method of production - In this case the birds are totally stayed in controlled condition in the cages so that the predators and other birds cannot come in contact of the poultry birds. In this method compulsory supplementary feeding is needed.

Night shelter method of production - In this case the birds are released for the scavenging in the day time and come inside the home in night, in the case of rain and winter they stay in home only until hungry.

In Betanoti $100 \%$ families followed the night shelter method for the backyard poultry cultivation.

\section{Feeding}

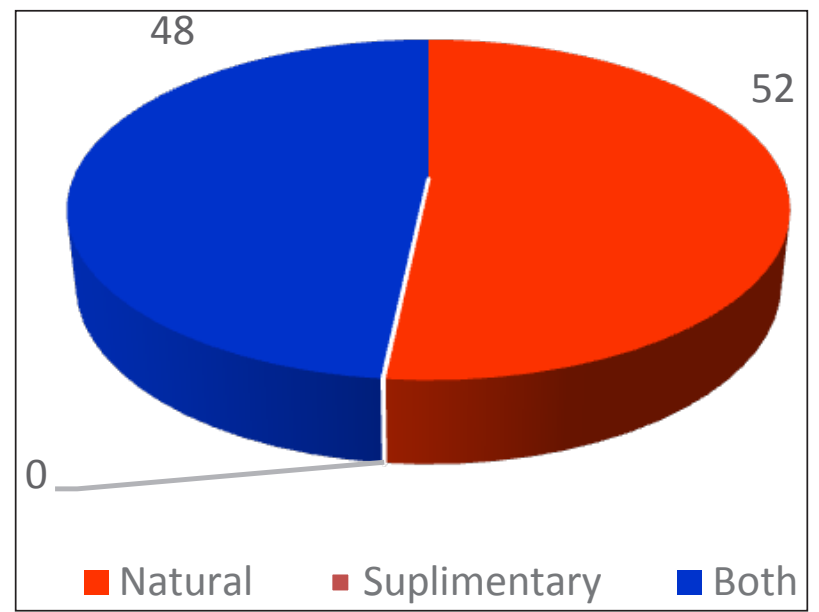

Chart 2: Types of feeding adopted by the farmers

Mainly the backyard poultry birds prefer to collect their own food by scavenging, but due to the high population in a single place the competition for the food is very high and most of the birds do not get the proper nutrition. As a result the growth rate become very low. Sometime people provide paddy or rice to the birds, what can be consider as the external feeding. From chart 2 it is clear that the most of the farmers do not give any supplementary feeding to their birds only $48 \%$ farmers give their birds little rice or paddy with scavenging for the faster growth, but there are $52 \%$ family is there which do not give any supplementary feeding to their chick for better growth.

From the table 2 it is clear that the persons who do only natural feeding their hens give on an average 13 eggs in a cycle and those who do a little supplementary feeding they get an average of 15 eggs per cycle. 
Table 2: Average egg laying capacity based on the types of feeding

\begin{tabular}{ll}
\hline Feeding type & $\begin{array}{l}\text { Average Egg per } \\
\text { bird per cycle }\end{array}$ \\
\hline Natural Feeding & 13 \\
Natural and Supplementary & 15 \\
\hline
\end{tabular}

\section{Medical care}

Poultry birds are highly vulnerable to the disease and parasites it adversely effects the growth rate and also effects the longevity of a bird.

Table 3: Percentage of farmers who take medical care and who do not take medical care to the birds

\begin{tabular}{ll}
\hline Medical care & Percentage \\
\hline Taken & 28 \\
Not Taken & 72 \\
\hline
\end{tabular}

The above table is the representation of the situation of the block about the medical care of the birds. Only $28 \%$ farmers take the medical care of the birds and $72 \%$ farmers do not take the medical care of the birds. Sometimes the access of medical facility is not there and sometimes due to the ignorance of the farmers who do not think the vaccination and the deworming as a necessary thing.

The chart 3 clearly mentioned that the birds which are minimum medically treated have a mortality of $31 \%$ and which birds are not medically treated have a mortality rate of $43 \%$ which leads a huge loss to the livelihood.

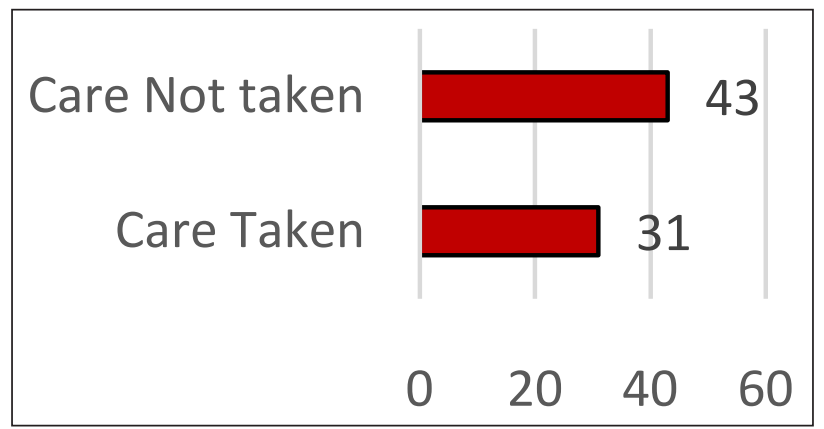

Chart 3: Rate of mortality in birds

\section{Products}

Mainly they sold the birds alive, either for fight or for the meat. The price of birds for fight is very high in compare to the birds for meat, but they have certain parameters for that, all birds cannot be fit into that and the only cocks are eligible for the fight purpose. From the analysed data of collected information the ratio between the selling of birds for fight and birds for meat is 1:10. No one sell eggs all eggs are preserve for hatching. Hence from the table 3 it is clear that the 100 percent farmers sell the birds for meat, but only 27 per cent farmer sale both, and no one sell egg in market.

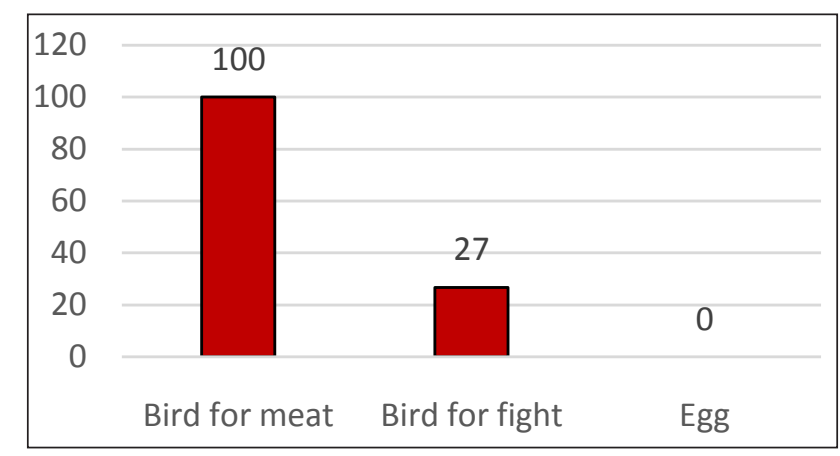

Chart 4: Products for selling

\section{Marketing}

From the information collected during survey it was observed that $65 \%$ of the farmers sell their products through direct marketing method. And only $35 \%$ people sell their product in the indirect method. Indirect marketing have two levels of middleman between farmer and consumer i.e. bird collectors and the retailer.

\section{Economics of the bird collectors' annual transaction (Level 1 middleman)}

Table 4: Costs in the business of the bird collector

\begin{tabular}{ll}
\hline Particular & Costs \\
\hline Cost of meat bird (₹/kg) & 277 \\
Number of meat bird purchase & 133 \\
Total Cost for Meat birds & 73593 \\
Cost of Fight bird $(₹ / \mathrm{kg})$ & 833 \\
Number of fight bird purchase & 15 \\
Total Cost for Fight birds & 31238 \\
Transport charge & 2960 \\
Other Marketing charges & 1480 \\
\hline Total cost & $\mathbf{1 0 9 2 7 1}$ \\
\hline
\end{tabular}

From the table 4, it is clear that, what are the cost what a bird collector incurred during the business, the purchasing of the birds for different purpose in different rates to the marketing costs and some other marketing charges. It is nearly ₹ 109271 what he invests in the whole year business. 
Table 5: Details of the income of the Bird collector

\begin{tabular}{ll}
\hline Particulars & Costs \\
\hline Number of meat bird sell & 133 \\
Average weight of meat bird & 2 \\
Selling price of meat bird & 320 \\
Total Income from meat birds & 78222 \\
Number of fight bird sell & 15 \\
Average weight of fight bird & 2.5 \\
Selling price of fight bird & 1300 \\
Total Income from fight birds & 48750 \\
Gross Income & 126972 \\
Net Income & 17701 \\
\hline B:C ratio & 1.2 \\
\hline
\end{tabular}

From the table 5, it is clear that, an annual income of ₹ 126972 he is earning what is the gross income, the net income is ₹ 17701 in a year and the benefit: cost ratio is 1.2 for this livelihood.

One malpractice they do before selling the birds to the customer, they mix sand with the feed of bird and give the birds a lot of feed on the morning of selling it. The birds eat all the feed along with sand and become heavy in weight what helps them to get more income as they sold the bird in terms of weight.

\section{Details about the retailer (level 2 middleman)}

Retailers are also the independent businessman who usually sale the meat only. Their main customers are hotels or regular consumers.

\section{Economics of the retailer's annual income}

Table 6: Costs in the business of the retailer

\begin{tabular}{ll}
\hline Particulars & Costs \\
\hline Cost of Purchas $(₹ / \mathrm{kg})$ & 320 \\
Number of meat bird purchase & 230 \\
Average weight of bird $(\mathrm{kg})$ & 2 \\
Total Cost for birds & 147200 \\
Transport charge & 0 \\
Other Marketing charges & 2900 \\
\hline Total cost & $\mathbf{1 5 0 1 0 0}$ \\
\hline
\end{tabular}

Table 6 is clarifying all the costs present in the annual business of a retailer. It includes the purchasing of bird, and some other marketing cost like feeding of the bird, rent of the shop etc. on an average annually he have to incest ₹ 150100 .
From the table 7 it can be told that from the $2 \mathrm{~kg}$ of bird only $1.5 \mathrm{~kg}$ of meat can be recover. And the selling price of the meat is nearly ₹ 410 per $\mathrm{kg}$ of meat. Then the retailer have a gross income of $₹ 141450$ and a net income of ₹ 0 annually. They are running in loss. He achieved a Benefit: cost ratio of 0.94. It means the business somehow recover his all cost from the business.

Table 7: Details of the income of the retailer

\begin{tabular}{ll}
\hline Particulars & Costs \\
\hline Number of meat bird sell & 230 \\
Average weight of bird $(\mathrm{kg})$ & 2 \\
Average weight of meat & 1.500 \\
Price/kg & 410 \\
Gross Income & 141450 \\
Net Income & -8650 \\
B:C ratio & 0.94 \\
\hline
\end{tabular}

\section{Details about the consumers}

For the study 10 consumers are randomly selected in the study location and asked question about the consumption of chicken. From the surveyed 10 household every household is non-vegetarian. And among the all family members $97 \%$ eat chicken. Annually one family having chicken on an average 42 days. And average annual consumption is nearly $65 \mathrm{~kg}$ per year.

Table 8: Details about the 16 different type of value chain

\begin{tabular}{|c|c|c|c|}
\hline $\begin{array}{l}\text { Case } \\
\text { No }\end{array}$ & Details & Elaborative Details & B:C \\
\hline $\begin{array}{l}\text { Case } \\
1\end{array}$ & $\begin{array}{l}\mathrm{N}+\mathrm{M}+\mathrm{D} \\
\quad+\mathrm{H}\end{array}$ & $\begin{array}{l}\text { Natural feeding + Medical care taken } \\
+ \text { Direct marketing + Home source }\end{array}$ & 3.7 \\
\hline $\begin{array}{l}\text { Case } \\
2\end{array}$ & $\begin{array}{l}\mathrm{N}+\mathrm{M}+\mathrm{D} \\
\quad+\mathrm{S}\end{array}$ & $\begin{array}{l}\text { Natural feeding + Medical care taken } \\
+ \text { Direct marketing + Sharing source }\end{array}$ & 1.8 \\
\hline $\begin{array}{l}\text { Case } \\
3\end{array}$ & $\begin{array}{l}\mathrm{N}+\mathrm{M}+ \\
\mathrm{InD}+\mathrm{H}\end{array}$ & $\begin{array}{l}\text { Natural feeding + Medical care taken } \\
+ \text { Indirect marketing + Home source }\end{array}$ & 3.8 \\
\hline $\begin{array}{l}\text { Case } \\
4\end{array}$ & $\begin{array}{l}\mathrm{N}+\mathrm{M}+ \\
\mathrm{InD}+\mathrm{S}\end{array}$ & $\begin{array}{l}\text { Natural feeding + Medical care } \\
\text { taken + Indirect marketing + Sharing } \\
\text { source }\end{array}$ & 1.9 \\
\hline $\begin{array}{l}\text { Case } \\
5\end{array}$ & $\begin{array}{c}\mathrm{N}+\mathrm{MN}+ \\
\mathrm{D}+\mathrm{H}\end{array}$ & $\begin{array}{l}\text { Natural feeding + Medical care not } \\
\text { taken + Direct marketing + Home } \\
\text { source }\end{array}$ & 3.3 \\
\hline $\begin{array}{l}\text { Case } \\
6\end{array}$ & $\begin{array}{c}\mathrm{N}+\mathrm{MN}+ \\
\mathrm{D}+\mathrm{S}\end{array}$ & $\begin{array}{l}\text { Natural feeding + Medical care not } \\
\text { taken + Direct marketing + Sharing } \\
\text { source }\end{array}$ & 1.6 \\
\hline
\end{tabular}


Case $\mathrm{N}+\mathrm{MN}+$ Natural feeding + Medical care not

$7 \mathrm{InD}+\mathrm{H}$ taken + Indirect marketing + Home source

Case $\mathrm{N}+\mathrm{MN}+$ Natural feeding + Medical care not 1.7

$8 \mathrm{InD}+\mathrm{S}$ taken + Indirect marketing + Sharing source

Case B + M+ D Both feeding + Medical care taken + 3.3

$9+\mathrm{H}$ Direct marketing + Home source

Case B + M+ D Both feeding + Medical care taken + 1.6

$10+\mathrm{S}$ Direct marketing + Sharing source

Case $\mathrm{B}+\mathrm{M}+$ Both feeding + Medical care taken +3.3

$11 \mathrm{InD}+\mathrm{H}$ Indirect marketing + Home source

Case $\mathrm{B}+\mathrm{M}+\quad$ Both feeding + Medical care taken +1.7

$12 \mathrm{InD}+\mathrm{S}$ Indirect marketing + Sharing source

Case $\mathrm{B}+\mathrm{MN}+$ Both feeding + Medical care not $\quad 3.4$

$13 \mathrm{D}+\mathrm{H}$ taken + Direct marketing + Home source

Case $\mathrm{B}+\mathrm{MN}+$ Natural feeding + Medical care not

$14 \mathrm{D}+\mathrm{S}$ taken + Direct marketing + Sharing source

Case $\mathrm{B}+\mathrm{MN}+$ Both feeding + Medical care not

$17 \mathrm{InD}+\mathrm{H}$ taken + Indirect marketing + Home source

Case $\mathrm{B}+\mathrm{MN}+$ Both feeding + Medical care not $\quad 1.7$

16 InD $+S$ taken + Indirect marketing + Sharing source

\section{Gaps that limiting the profit of the farmer}

From the collected information during sample survey and through FGD it was found that there are 16 different type of practices exist in the system in terms of production and marketing methods. From the sample taken an average of two male and three female flock size found in each family, keeping that as a stander unit flock size of five it the cost of production has been calculated. Then according to the unite flock size their benefit cost ratio is clearly described in table no 15 of sixteen different practices.

From the table no 8 it is found that case no 3 (Natural feeding + Medical care taken + Indirect marketing + Home source) is giving the most profitable output and the case no 6 (Natural feeding + Medical care not taken + Direct marketing + Sharing source), 10 (Both feeding + Medical care taken + Direct marketing + Sharing source) and 14 (Natural feeding + Medical care not taken + Direct marketing + Sharing source) giving the lowest output. From the findings of the review of literature all the literature refers that is supplementary feeding is given then production will increase, if medical care is taken then mortality will decrease and if marketing channel will be direct then the income of the farmers will definitely increase. But in the case of this study it is clear that production increased due to supplementary feeding, mortality also decrease due to the medical care and farmers are also getting better price if they do the direct marketing, but still the results telling that case no 9 (Both feeding + Medical care taken + Direct marketing + Home source) is giving a lower $\mathrm{B}: \mathrm{C}$ ratio of 3.3 where the case no 3 (Natural feeding + Medical care taken + Indirect marketing + Home source) is giving the most profitable output with a $\mathrm{B}: \mathrm{C}$ ratio of 3.9. So it can be said from the findings that in this case investment in case 9 (Both feeding + Medical care taken + Direct marketing + Home source) is a double loss practice where they can get a better output through the case no 3 (Natural feeding + Medical care taken + Indirect marketing + Home source). The practice of the sharing method may be limit the profit of the farmer in the initial period that's why the case no 6 (Natural feeding + Medical care not taken + Direct marketing + Sharing source), 10 (Both feeding + Medical care taken + Direct marketing + Sharing source) and 14 (Natural feeding + Medical care not taken + Direct marketing + Sharing source) giving the lowest output, but it is a beneficial and viable method for a very poor farmer who do not have enough cash to purchase a pair of birds for rearing from the market, after one year this farmer also comes under a regular flow of profit.

But according to the all experts of KVK and veterinary department they clearly suggest the modern way of vaccination, feeding and direct marketing methods to the farmers, but from the findings it should not be suggested by a researcher. Like the green revolution this sector is also not an exception, all the modern medicines and feedings are of high cost and the breeds like broiler response very good on that. But in such case of supreme negligence broiler is not a viable breed to cultivate. So with the very low unit flock size and slow growing breeds cannot meet the cost of extra care, may be it will cross the investment cost in return with a $\mathrm{B}: \mathrm{C}$ ratio of more than 3 if we not calculate the opportunity cost of the farmers. In case of suggesting those high cost methods to farmers they will only listen in the meetings and go for their indigenous nature as it will give more 
Framework for Better Understanding of value chain
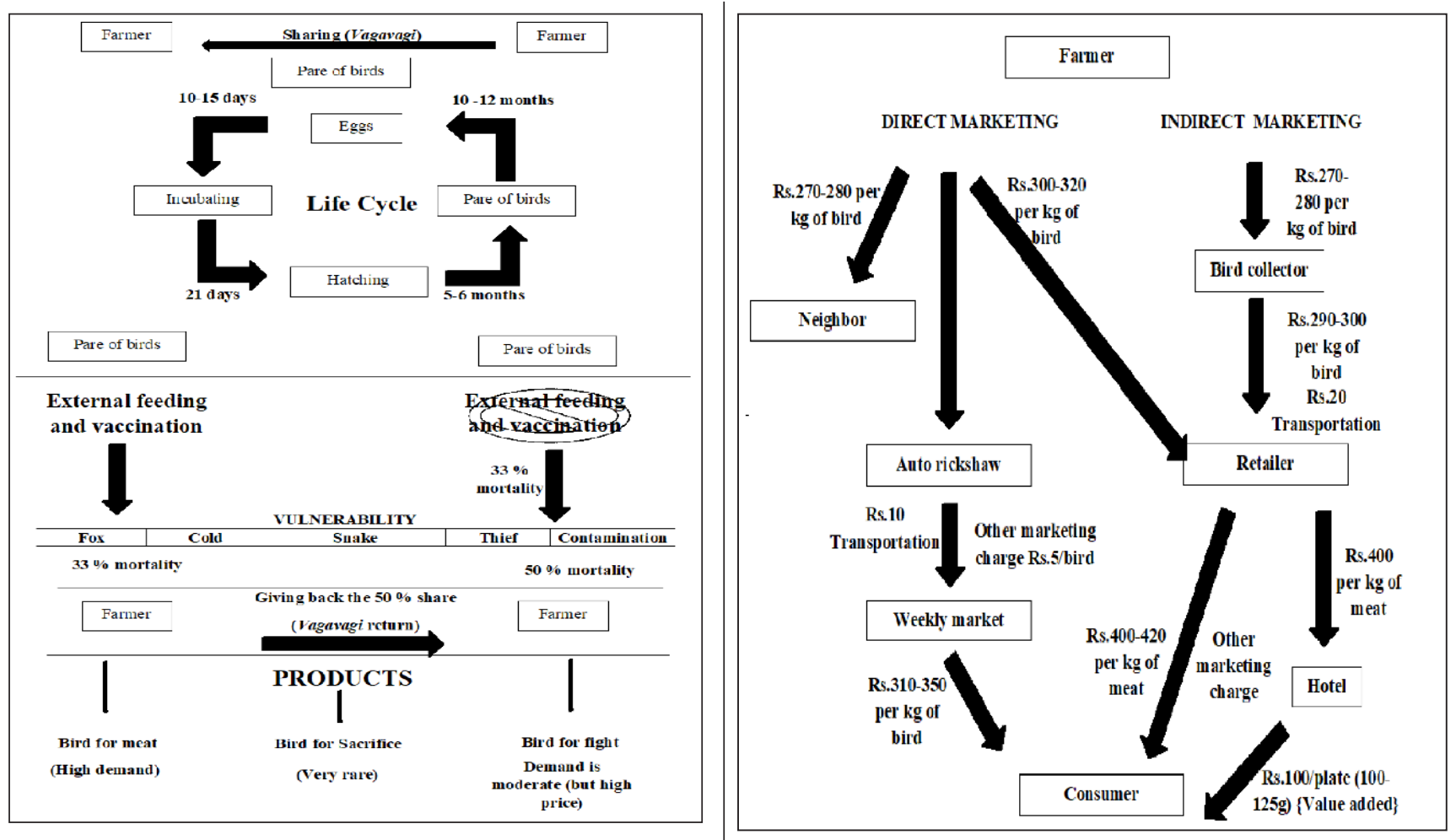

Fig. 1: Value chain of Back Yard Poultry

output in less investment of money and labour. Actually the problem is all the farmers in the locality do not go for the vaccination so may a farmer have taken the medical care but from the other unvaccinated birds the vaccinated birds get infected and thus they become as vulnerable to the disease as the unvaccinated birds, and during the time of scavenging birds have intake a lot of worms in the stomach as a result the supplementary feeding of only rice do not work as effective as the birds who are reared in the cage. Not only that if they go for direct marketing the interior villagers also have to came to city with a transportation cost of ₹ 20 per bird and some other cost of the transportation of the farmers also. And the opportunity cost of the farmers own labor of that day is calculated then again a loss of ₹ 330 will be there which will limit the profit of the farmers. In case of indirect marketing may be the farmers get lesser price than the direct marketing but, there is zero opportunity cost they have to spend. Other than that the slow growth rate, attack of the predators, changing temperature sometimes causes a huge loss to the farmers.

\section{CONCLUSION}

Odisha is a state of forest and coastal areas, Mayurbhanj district is famous for it's wield flocks and backyard poultry. As it was discussed previously poor people take this poultry as the savings of sudden needs they do it for a backup. From the findings it is clear that may not be the majority but a huge number of population in the area doing the poultry for their own consumption and own need purpose, $45 \%$ people expect a substantial output from the livelihood, there are $55 \%$ population who do it in a commercial way but it is not in a large scale. This leads problem of marketing also in reality, in such a small scale going to the market and sell just one or two bird is not viable for the business also. For that much light concentration and care the production is very low in the area. In the naked eyes it is true that the rate of direct marketing is high in this area. But the truth is people sell directly to the market in a very less number. The farmers who are doing the poultry in the substantial level they also sale the products either to the neighbour or any local vender and exchange goods in need, so they are 
selling it directly to the consumer, but it is not a commercial marketing it is substantial. From the above findings it can be observe that there is a problem in the scaling up. As the farmers are poor it is very difficult for them to scale it up. But on the other hand it will be better to form groups among the farmers and start the livelihood with scientific manner. It will give the farmers many benefits socially and institutionally.

1. It will reduce the transportation cost.

2. It will reduce the disease due to the contamination.

3. It will reduce the threat of predator and thief. If the backyard poultry is deeply analyze as a livelihood of the poor of Odisha, it can be said that it is the best alternative as a livelihood. No need of much more care, low input cost and high demand of the products clarify the statement. The government of Odisha is also launch a scheme for getting easy finance of up to ₹ 2 lakh for one year to scale up the poultry in the state. So in this circumstances it is one of those opportunities what everyone should grab. But from the study and also from the collected information from the different institution it was known that, there is no insurance product for the back yard poultry, but there are insurance product for back yard cow or goat. So any further study which deeply study the vulnerabilities and make a suitable insurance product for backyard poultry it will be very helpful to the community.

\section{ACKNOWLEDGEMENTS}

This research work was financially supported by the host institute (The DHAN Academy) itself and the author express his deepest sense of gratitude to the concerned authority of the institute for financial assistance towards accomplishing the research. The author also very grateful to DHAN Foundation Betanati and the community of the villages.

\section{REFERENCES}

Asem-Bansah, C.K., Sakyi-Dawson, O., Ackah-Nyamike, E.E., Colecraft, E.K. and Marquis, G.S. 2012. Enhancing backyard poultry enterprise performance in the Techiman area: A value chain analysis. African Journal of Food, Agriculture, Nutrition and Development, 12(1): 5759-5775.

Bwalya, R. and Kalinda, T. 2014. An analysis of the value chain for indigenous chickens in Zambia's Lusaka and Central Provinces. Journal of Agricultural Studies, 2(2): 32-51.

Hailemichael, A., Gebremedhin, B., Gizaw, S. and Tegegne, A. 2016. Analysis of village poultry value chain in Ethiopia: Implications for action research and development.

19 Livestock Census-2012 All India Report - Retrieved on May 26, 2020 http://dahd.nic.in/sites/default/filess/ Livestock\%20\%205_0.pdf

National Action Plan for Egg \& Poultry-2022 for Doubling Farmers' Income by 2022 - Retrieved on May 26, 2020 - http://dahd.nic.in/sites/default/filess/Seeking $\% 20$ Comments\%20on\%20National\%20Action\%20Plan-\%20 Poultry-\%202022\%20by\%2012-12-2017_0.pdf

Rath, P.K., Mandal, K.D. and Panda, P. 2015. Backyard poultry farming in India: A call for skill upliftment. Research Journal of Recent Sciences, 4: 1-5.

Khatun, R., Ahmed, S., Hasan, M.A., Islam, M.S., Uddin, A.A. and Mahmud, M.S. 2016. Value Chain Analysis of Processed Poultry Products (Egg and Meat) in Some Selected Areas of Bangladesh. American Journal of Rural Development, 4(3): 65-70.

Mandal, M.K., Khandekar, N. and Khandekar, P. 2006. Backyard poultry farming in Bareilly district of Uttar Pradesh, India: an analysis. Livestock Research for Rural Development, 18(7): 2006.

Okello, J.J., Gitonga, Z., Mutune, J., Okello, R.M., Afande, M. and Rich, K.M. 2010. Value chain analysis of the Kenyan poultry industry: The case of Kiambu, Kilifi, Vihiga, and Nakuru Districts.

Patbandha, T., Pathak, R., Maharana, B., Marandi, S. and Sardar, K. 2016. Traditional rural chicken production in northern Odisha: Gender role and decision making. International Journal of Science, Environment and Technology, 5(2): 489-498.

Pathak, P.K. and Nath, B.G. 2013. Rural poultry farming with improved breed of backyard chicken. J. World's Poult. Res., 3(1): 24-27.

Sethi, B. 2007. Backyard Poultry in Orissa. Orissa Review, pp. 48-52.

Zeberga, A. 2010. Analysis of poultry market chain: The case of Dale and Alaba 'Special'Woredas of SNNPRS, Ethiopia (Doctoral dissertation, Haramaya University). 